curiosity aroused by the icebergs and aurora borealis of his native province, ran away to school in Moseow at the age of nineteen. He entered the Germanstaffed Academy of Sciences set up by Peter the Great, being the first Russian to do so, and the first to lecture in his native tongue instead of in Latin.

He propounded theories on the structure of matter, the kinetic theory of gases, and the mechanical theory of heat, a hundred years in advance of their general introduction; he built a 'thunder-machine' to study electricity; he wrote about the physical condition of the sun, the atmosphere of Venus, metallurgy, and gravity; he was the first to point out the possibility of the passage now established as the Great Northern Sea Route; he published the first Russian grammar and founded the University of Moscow. Because he was only one outstanding figure in an age of absolutism, much of his work perished with him, and his importance as a pioneer has only recently been recognized. Further information concerning the lecture can be obtained from the Secretary, S.C.R., 98 Gower Street, London, W.C.l.

\section{The British Pharmaceutical Conference}

THE seventy-sixth annual meeting of the British Pharmaceutical Conference was the briefest in its annals. It was held at the headquarters of the Pharmaceutical Society on the afternoon of June 11, and the proceedings were limited to the address of the chairman, Mr. H. Humphreys Jones. The theme of the address was the role of pharmacists in relation to the food problem. He said that physiology is an integral part of the curriculum of study of the pharmaceutical student. Items in the syllabus are the physiology of the alimentary tract, comprising a knowledge of the control of salivary, gastric, pancreatic and biliary secretion. The chemistry of certain specified food sustances and the properties of the digestive juices and bile are also subjects of the curriculum. The main reason for their inclusion is, he said, the acceptance of the fact that pharmacists must keep pace with medical progress, and a further reason is the necessity for the pharmacist to be alive to the general awakening regarding food values. He must know not only the pharmacopœia -in which standards are laid down for certain organo-therapeutical substances, such as insulin, pituitary and thyroid as well as sera and vaccines-but also the chemistry of meat, eggs and bread and the properties of the digestive juices.

Mr. Humphreys Jones argued that, while in the past the aim of pharmacy has been to provide drugs to cure diseases rather than to prevent them, a wider vista has been opened up which invites the application of the knowledge of food values with a view to the prevention of disease and the maintenance of a general high standard of health at all periods of life. It has long been recognized that rickets, scurvy and many other diseases are due to the absence of certain food constituents; this emphasizes the desirability of the close study by students of this part of the curriculum. In this connexion he said, "The [Pharma- ceutical] Society has already done good work in connexion with vitamins. But why regard vitamins as the only important ingredients in real food?" Hitherto, he said, the pharmacist has depended. almost exclusively upon his own initiative and ingenuity; as a servant of the State, his main privilege is that he can sell and dispense scheduled poisons and dispense medicines under the National Health Insurance Act. In Mr. Jones's view, there ought to be an avenue through which the pharmacist's knowledge of nutrition would be similarly recognized; if a person is compelled by the State to pass an examination in a subject of first-class importance, he should be provided with the opportunity of utilizing that knowledge in the public service. In short, the public should be taught to regard the pharmacist as a dietitian.

\section{The Institution of Professional Civil Servants}

THe twenty-first annual report of the Council of the Institution of Professional Civil Servants, presented to the annual general meeting on April 25, indicates that in spite of the pre-occupation of Government departments, and especially the defence departments, with more pressing issues than service conditions, the Council has been available to secure a considerable number of increases in salary and other improvements in the conditions of employment. The report gives a review of activities which shows that the Council has fully maintained its vigilance over the interests of members in the difficult conditions of war-time, despite the removal to temporary offices and the heavier responsibilities falling on the honorary officers since the usual method of control by Council and its committees came in abeyance, and that claims or representations have been preferred with a sense of proportion and balance highly creditable to the Institution.

Special attention is given in the report of the Institution to numerous problems arising out of the evacuation of civil servants, of whom to date about 20,000 have been transferred to provincial towns. Concessions have been secured in regard to visits to families, billeting payments, daily travelling expenses and the like, and the formation of committees of the staffs of evacuated departments in the reception towns is being attempted. Numerous details are included in the report of representations on matters affecting the staffs of Government scientific establishments.

\section{Scientific Films in War-Time}

THE London Scientific Film Society gave four shows last winter of scientific and documentary films and received encouraging support. A new form of programme was generally appreciated. Several films with a common subject or theme were shown together ; programmes on contrasting or complementary treatments of psychology, civics in Great Britain, and agriculture being presented. All films shown by the Society are approved by the Scientific Films Committee of the Association of Scientific Workers, 30 Bedford Row, London, W.C.1. This body was set 